Article

\title{
Sustaining the Effective Use of Materials in Language Classrooms: A Conceptual Understanding of Teacher Knowledge for Materials Use
}

\author{
Zhan $\mathrm{Li}^{1}{ }^{1}$ and Yueting $\mathrm{Xu}^{2, *}$ \\ 1 School of Foreign Languages, Zhongnan University of Economics and Law, Wuhan 430073, China; \\ lzflower@zuel.edu.cn \\ 2 School of Foreign Languages, South China Normal University, Guangzhou 510641, China \\ * Correspondence: traceyxu@gdufs.edu.cn
}

Citation: Li, Z.; Xu, Y. Sustaining the Effective Use of Materials in

Language Classrooms: A Conceptual Understanding of Teacher Knowledge for Materials Use.

Sustainability 2021, 13, 8115.

https://doi.org/10.3390/su13148115

Academic Editors: Lawrence Zhang and Vincent T. Greenier

Received: 4 June 2021

Accepted: 14 July 2021

Published: 20 July 2021

Publisher's Note: MDPI stays neutral with regard to jurisdictional claims in published maps and institutional affiliations.

Copyright: (c) 2021 by the authors. Licensee MDPI, Basel, Switzerland. This article is an open access article distributed under the terms and conditions of the Creative Commons Attribution (CC BY) license (https:/ / creativecommons.org/licenses/by/ $4.0 /)$.

\begin{abstract}
Materials use is a critical yet understudied domain of language teaching across jurisdictions and educational contexts. This study explored what knowledge constituents that English-as-a-foreignlanguage (EFL) teachers mobilize in their use of materials. Based on the social theory of human cognition in tool use and the conception of foreign language teachers' pedagogical content knowledge, a qualitative multi-case study involving eight EFL teachers at one university in China was conducted. Data from interviews, lesson observations, and documents across three consecutive semesters revealed that teacher knowledge for materials use is multi-dimensional and developmental. The constituents of this professional knowledge are manifested in four domains, i.e., subject matter, pedagogical, curricular, and contextual domains. The study concluded that the professional knowledge needed for materials use is not merely an individual trait, but mediated by both human and nonhuman elements. Therefore, new forms of agency from both teachers and materials are required to foster the growth of this professional knowledge. Based on the findings, suggestions were made for teacher learning through materials use in language classrooms.
\end{abstract}

Keywords: language teacher; materials use; teacher knowledge in materials use; teacher learning

\section{Introduction}

Language materials, a ubiquitous and essential element of language classrooms, function as the de facto curriculum in foreign or second-language teaching worldwide [1-4]. Although new curriculum materials have the potential to bring novel instructional practices into classrooms [5,6], their success is highly dependent on teachers' ability to unlock educational potential, translate embodied pedagogical goals into teaching, and incorporate those goals into students' learning experiences $[7,8]$.

It has been broadly accepted that teacher knowledge makes a significant contribution to effective teaching and student learning [9-11]. Recent research on materials use in language education, or "the ways that participants in language learning environments actually employ and interact with materials" [12] (p. 38), has noted the mediating role of language teachers' expertise in materials use. However, despite the ubiquity of materials in language education and the decisive role of teacher knowledge in teaching, the literature in TESOL as a whole lacks an explicit focus on the knowledge base that language teachers draw on to use materials effectively for teaching. Furthermore, there has been no precise outline of this professional knowledge to inform the sustainability of the teaching profession in terms of materials use. Indeed, materials use research is widely acknowledged as the least-studied area in applied linguistics $[13,14]$. Thus, the community of language education is in dire need of an in-depth understanding of this prevalent yet understudied domain of teaching.

To fill this gap, we designed a qualitative multi-case study involving eight EFL teachers at one university in China. The assumption that underpinned our study was that the 
productive use of materials requires considerable knowledge and skills on the part of teachers [15]. Learning more about the knowledge base that teachers draw on in materials use is an important agenda for the sustainability of the teaching profession [16-18]. Thus, our goal was to understand this professional knowledge by outlining its possible components. It is hoped that this conceptual study could advance our understanding of materials use and could have implications for promoting teacher learning and development through materials use.

Two research questions were then raised to direct the study:

1. What are the components of knowledge that EFL teachers possess and deploy in the practice of materials use?

2. How do teachers use and develop the professional knowledge for materials use to sustain the effective use of materials?

\section{Literature Review}

We begin our literature review by clarifying terms that have been used in materials-use research. The terms instructional materials, textbooks, and language materials are often used interchangeably in English Language teaching (ELT) contexts to refer to the legitimate role of teaching materials [3,4]. Here, we define materials broadly, referring to the syllabus, Student's Book, Teacher's Guide, auxiliary PowerPoint slides. teacher-prepared PowerPoint slides, and additional materials that teachers and learners use for teaching and learning. In the institution under study, the PowerPoint slides were designed by the publishing house as auxiliary teaching materials for teachers, whose use was prescribed together with the target textbook series. In the context of curriculum studies, the term enactment emphasizes that knowing is an action in and of itself [19] rather than a perception or representation [20]. This view also echoes the ecological lens [8], new materialism theory [21], and socio-material perspectives [22] of language educational research, in that materials use is enmeshed with social, technical, and personal processes (see, for example, the special issue about materials use published by The Modern Language Journal in 2021). Here, we use enact and use interchangeably to refer to how teachers' objectives are translated into their teaching practice.

\subsection{Materials Use in Language Classrooms}

Only recently have researchers begun to explore how and why materials are used in language classrooms [4,23]. Research asking how has largely examined the role of materials in language teaching and learning and teachers' approaches to using materials. For instance, examining the use of an English grammar textbook at a public university in the U.S., Guerrettaz and Johnston [24] found that classroom discourse was strongly influenced by the materials used in terms of their topic, type, and organization within the classroom ecology. In Shawer's [25] examination of the classroom-level curriculum development of 10 EFL college teachers in the U.K., teachers were categorized as curriculum developers, makers, or transmitters, who demonstrated agentive power in materials use. The studies asking why materials are used in particular ways in language classrooms have focused on the factors influencing materials use, including teacher resources, student factors, and some contextual factors. These factors have been identified across regional contexts, such as China [26], Japan [27], the U.K. [28], and Ghana [29].

All of the above studies agreed on the multi-faceted, interactive, and context-driven nature of materials use. Due to its manifold nature, materials use shapes and is shaped by other elements of classroom ecology. Among these elements, the teacher cognition was found to considerably influence decisions related to materials use [30]. However, teacher knowledge for materials use — the crucial concern of materials use research [31] — has only been referenced on a general level [32], rather than being rigorously examined, in foreign language scholarship [33]. 


\subsection{Language Teacher Knowledge Regarding Materials Use}

Research on language teacher knowledge has examined varied aspects of this construct with reference to different concepts, such as maxims [34], beliefs, attitudes, knowledge [35], pedagogical knowledge [36-39], pedagogical principles [40], personal practical knowledge [41,42], and language awareness [43]. However, in TESOL scholarship, knowledge for materials use is still in its infancy [1]. Therefore, the knowledge of teacher knowledge for materials use is still insufficient. For instance, Tsui and Nicolson [44] regarded management of resources as one branch of English as a Second Language pedagogical content knowledge (PCK) or ensuring "the authenticity and appropriacy of the linguistic materials" for teaching (p. 220). Richards [32] pointed out that second language (L2) teachers should have the capacity to evaluate, choose, and adapt commercial and authentic materials, and included it as one of the ten core competencies of L2 teaching. We then argue that the literature in TESOL lacks an explicit focus on and construction of this professional knowledge.

\subsection{Teacher Knowledge of Materials Use in General Education}

Despite the dearth of research on material use in language education on a global level [4], some notable studies $[45,46]$ have explored issues around the knowledge required for teaching, particularly in terms of enacting curriculum materials for mathematics and science in the U.S. These studies have delineated the possible knowledge landscapes that teachers might traverse to use materials. The stock of knowledge [47] that teachers deploy is distributed across four areas, namely, curriculum materials [6], disciplines [48,49], students [50], and contexts [51]. The view of knowledge as distributed holds that teachers actively interact with multiple knowledge resources to design and enact instruction [30,52]. Moreover, knowledge is both distributed and held by individuals and carried by resources [6]. Teachers need to draw on various types of knowledge to transform a written and intended curriculum into an enacted one. Conceptualizing the knowledge required to enact curriculum materials in mainstream education sheds light on the potential types of knowledge possessed by teachers, embodied in materials, and situated in the classroom ecology, as well as the categorizable nature of this professional bulk of knowledge.

\subsection{Connecting the Research of Materials Use to the Construct of Agency}

Teacher agency is the "willingness and capacity to act according to professional values, beliefs, goals, and knowledge in the different contexts and situations that teachers face in their work" [53] (p. 616). Language teacher agency refers to "a language teacher's intentional authority to make choices and act accordingly in his or her local context" [54] (p. 29). Both definitions highlight the context-driven nature of teacher agency. Thus, an important connection can be drawn between materials use and the construction of the agency. Due to the adaptive nature of materials use in language classrooms, materials use is part of the process of developing agency [55]. In other words, the extent to which teachers can effectively use materials to design and enact instruction in divergent language classrooms reflects the degree to which they can exercise their agency. Teachers are the producers of knowledge, based on which they might exercise agency and critically examine the real-world contexts presented in curriculum materials, modifying them to make more authentic connections with students' disciplinary practices inside and outside of school [56].

Meanwhile, materials are artifacts with both physical characteristics and cultural meaning $[57,58]$ and "carry intentions and norms of cognition and form part of the agency of the activity" [59] (p. 301). Thus, humans and nonhumans (e.g., artifacts) are entangled in ways which help explain how all entities, not just humans, have the potential to influence situations and shape event trajectories [20]. In materials use, the agency is situated in humans (including teachers, students, administrators, materials designers, etc.) and nonhumans (including materials, teaching environments, etc.), which both facilitate materials use. 


\section{Theoretical Framework}

This study built on Keller and Keller's [47] social learning theory of cognition in tool use to interpret how language teachers draw on knowledge in the processes of materials use. Knowledge here is defined as "the disparate and dynamic conceptual entities that individuals use in their various activities" [47] (p. 15). It refers to the information known to practitioners and that is applied in their work, but not the set principles that underlie a technology's operation. Epistemologically, this theory emphasizes situated, dynamic, and embodied knowing through doing. It also contextualizes human cognition in the activity of tool use. In other words, observable human behaviors result from goal-oriented knowledge through action. In fact, all human practices are goal-oriented and mediated by tools, which are both deployed and produced through the process of practice, and deeply rooted in a particular context [60]. Put simply, the activity of materials use is the result of a participatory relationship among teachers, students, and materials in specific educational contexts, which cannot be fully represented without considering all of these elements in the classroom ecology.

In this case, teaching through the use of materials is analogous to the human activity of tool use for creative production. Materials serve as tools, and teachers are the designers of their own teaching, with the agency to mobilize various knowledge resources to accomplish their pedagogical and curricular goals [48]. The visible practice of their materials use is governed by teachers' cognitive processes, whereby an amalgam of knowledge is recruited and activated to accomplish the desired pedagogical and curricular goals. This professional knowledge is not a mere individual trait, but partly possessed by teachers, partly embodied by materials, and partly situated in the classroom ecology $[30,61,62]$.

\section{Methodology}

As materials use is contextually specific, a qualitative case study is appropriate, providing invaluable and in-depth insights into a complex social issue in a cultural context $[63,64]$.

\subsection{Setting and Target Materials}

This study was conducted in China, where there are currently more than 26 million university students [65]. The setting was chosen as a typical institution in Chinese higher education due to its level (i.e., funded by the "Double First-Class" project) and its efforts to promote College English (C.E.) reform (e.g., selected as a representative university for C.E. reform by the Ministry of Education in 2005). The Chinese Ministry of Education recently launched the Double First-class project to expand the number of highly ranked universities by 2050. The initial plan was to enhance 42 world-class universities and 95 universities with their first-class subject disciplines.

In China, all university students other than those majoring in English must take a compulsory English course, such as C.E., for at least one year, depending on their entrylevel English proficiency [66]. Textbooks for C.E. are compiled by scholars and adopted by local institutions to represent the designated curriculum [67]. At the beginning of each semester, a mandated syllabus is disseminated to every C.E. teacher at the target university, which covers the required teaching content (usually 6 out of 10 units from Book 1 to Book 3, and 3 out of 10 units in Book 4), the allocation of teaching time (eight successive periods per unit, including Reading and Writing and Listening and Speaking courses) and the arrangement of assessments. Theme-based CE textbooks have accordingly become the operational curriculum [68]. To date, more than 200 universities have adopted the target textbook series for C.E., meaning that nearly 2 million students are currently using the same textbooks in China.

\subsection{Participants}

The eight teacher participants were all non-native English speakers, each with a Master's degree in TESOL or another relevant discipline (e.g., applied linguistics). They were selected partly due to practical considerations and partly because they met the 
criterion of being information-rich cases [69]. The diversity of the participants' domains of expertise ensured a wide range of disciplinary knowledge. There were seven females and one male with ages ranging from 30 to 52 years. Their teaching experiences ranged from 2 to 27 years. All teachers were teaching the same course to students at the intermediate language proficiency level, using the same materials, and working at the target university. Each participant was assigned a code to protect confidentiality.

\subsection{Data Collection}

The primary data sources for this study included semi-structured interviews with the teachers, classroom observations, and documents. Before and after each class, the teachers were interviewed to discuss how they had designed their instruction and why they had made certain changes to their materials use (see Appendix A). Classroom observations were video recorded, and detailed field notes were taken by the first author. Table 1 summarizes the distribution of the lesson observations organized by teachers. Copies of all materials were collected, including the prescribed student's textbook, the teacher's guide, auxiliary PowerPoint slides, the teachers' own prepared PowerPoint slides, and all other supplementary materials. The study used methodological triangulation to collect a chain of evidence. The data collection methods captured what the participants wrote (documents), what they thought (interviews), and how they used materials in class (lesson observations). The data gathered through triangulation were then cross-analyzed to reveal the knowledge components demonstrated via the processes of materials use.

Table 1. Summary of lesson observations.

\begin{tabular}{|c|c|c|}
\hline Participant & $\begin{array}{l}\text { Teaching Materials and } \\
\text { Themes of Each Unit }\end{array}$ & $\begin{array}{c}\text { Number of Classes } \\
\text { Observed }\end{array}$ \\
\hline \multirow{3}{*}{$\mathrm{T} 2, \mathrm{~T} 8$} & Book II Unit 3 Credit cards & $3 \times 2=6$ \\
\hline & Book II Unit 4 News & $3 \times 2=6$ \\
\hline & Book II Unit 7 Animals & $4 \times 2=8$ \\
\hline \multirow{3}{*}{$\mathrm{T} 1, \mathrm{~T} 6, \mathrm{~T} 7$} & Book II Unit 3 Credit cards & $4 \times 3=12$ \\
\hline & Book II Unit 4 News & $4 \times 3=12$ \\
\hline & Book II Unit 7 Animals & $4 \times 3=12$ \\
\hline \multirow{5}{*}{$\mathrm{T} 3, \mathrm{~T} 4, \mathrm{~T} 5$} & Book I Unit 1 College life & $2 \times 3=6$ \\
\hline & Book II Unit 3 Credit cards & $3 \times 3=9$ \\
\hline & Book II Unit 4 News & $3 \times 3=9$ \\
\hline & Book II Unit 7 Animals & $3 \times 3=9$ \\
\hline & Book IV Unit 3 Literature & $3 \times 3=9$ \\
\hline \multicolumn{2}{|c|}{ Total } & 98 \\
\hline
\end{tabular}

\subsection{Data Analysis}

Based on the premise that designed and enacted instruction reflects key dimensions of teacher knowledge, we used a hybrid approach that combined grounded theory with deductive structural analysis to analyze the data in three phases. In the first phase, all of the interviews and lesson observations were transcribed verbatim. The observational data (in the form of classroom discourse) were analyzed using classroom discourse analysis, i.e., teacher initiation, student response, and teacher feedback or evaluation [70], to capture the enacted instruction. The documents were analyzed based on their content in relation to the specific knowledge required for teaching. The transcription conventions are provided in Appendix B. In the second phase, all data were coded based on a grounded-theory approach [71]. The coding was guided by our interest in capturing knowledge components represented in the physical artifacts (documentary data, observational data) and mentioned in mental artifacts (interview data). By looking for similarities and differences in the major 
constituents of knowledge regarding material use, we reached an agreement on the coding after rounds of negotiation. For instance, the codes for knowledge of the target language (KTL) included the following: "KTL inferred from teachers' statement," "KTL inferred from teachers' prepared materials," and "KTL inferred from enacted instruction." This procedure was implemented for each of the domains relating to the knowledge in materials use. In the third phase, based on König et al.'s [33] categorization of foreign language teacher's PCK (i.e., knowledge of curriculum, knowledge of teaching strategies and representations, and knowledge of students), we categorized the codes of teacher knowledge of materials use into four domains: subject matter, pedagogical, contextual, and curricular. Table 2 lists the major constituents in each domain of the knowledge for materials use with specific definitions and examples.

Table 2. Four domains of teacher knowledge for materials use.

\begin{tabular}{|c|c|c|}
\hline $\begin{array}{l}\text { Domains of } \\
\text { Knowledge }\end{array}$ & Knowledge Components & Example \\
\hline \multirow{3}{*}{ Subject matter } & $\begin{array}{l}\text { Knowledge of the target language, i.e., } \\
\text { knowledge of the language system, } \\
\text { including grammar, lexicon, semantics. }\end{array}$ & $\begin{array}{l}\text { T1's and T2's planned sample } \\
\text { sentences of the new } \\
\text { vocabulary "glide." }\end{array}$ \\
\hline & $\begin{array}{l}\text { Non-linguistic content knowledge, i.e., } \\
\text { knowledge of culture, other disciplines. }\end{array}$ & $\begin{array}{l}\text { The scope of T3's } \\
\text { supplementary materials is } \\
\text { related to her non-linguistic } \\
\text { content knowledge. }\end{array}$ \\
\hline & $\begin{array}{l}\text { Knowledge of the text, i.e., knowledge of the } \\
\text { structure of the passage, how and why the } \\
\text { text was written in that way [72]. }\end{array}$ & $\begin{array}{l}\text { T5's understanding of the } \\
\text { relationship between the } \\
\text { writer and Soren. }\end{array}$ \\
\hline \multirow{2}{*}{ Pedagogical } & $\begin{array}{l}\text { Knowledge of teaching strategies, i.e., } \\
\text { procedural knowledge of } \\
\text { instructional steps. }\end{array}$ & $\begin{array}{l}\text { T8's strategy of letting } \\
\text { students predict without } \\
\text { reading the whole passage. }\end{array}$ \\
\hline & $\begin{array}{l}\text { Knowledge of learning strategies, e.g., } \\
\text { cognitive, metacognitive, affective } \\
\text { strategies [73]. }\end{array}$ & $\begin{array}{l}\text { T5's instruction of reading } \\
\text { comprehension, i.e., read } \\
\text { between the lines. }\end{array}$ \\
\hline \multirow{3}{*}{ Contextual } & $\begin{array}{l}\text { Knowledge of students, i.e., knowledge of } \\
\text { students' language proficiency, needs, } \\
\text { interests, preferences. }\end{array}$ & $\begin{array}{l}\text { T4's supplementary material } \\
\text { of the map of the } \\
\text { target university. }\end{array}$ \\
\hline & $\begin{array}{l}\text { Knowledge of educational contexts, i.e., } \\
\text { knowledge of the institutional and } \\
\text { classroom rules. }\end{array}$ & $\begin{array}{l}\text { T6 shifted the focus of the } \\
\text { exam-oriented training. }\end{array}$ \\
\hline & $\begin{array}{c}\text { Knowledge of technology, i.e., knowledge of } \\
\text { using multimodal materials and } \\
\text { technological tools }\end{array}$ & $\begin{array}{l}\text { T3 redesigned PowerPoint } \\
\text { Slides; Teachers' } \\
\text { supplementary visual and } \\
\text { audio resources. }\end{array}$ \\
\hline \multirow{2}{*}{ Curricular } & $\begin{array}{l}\text { Knowledge of curricular documents, i.e., } \\
\text { knowledge of national } \\
\text { curriculum, syllabus. }\end{array}$ & $\begin{array}{c}\text { Teachers rescheduled teaching } \\
\text { plans based on the } \\
\text { set syllabus. }\end{array}$ \\
\hline & $\begin{array}{l}\text { Knowledge of design intentions, i.e., the } \\
\text { knowledge of pedagogical intentions } \\
\text { of materials. }\end{array}$ & $\begin{array}{l}\text { T7's failure of conducting the } \\
\text { chronological exercise in } \\
\text { the textbook. }\end{array}$ \\
\hline
\end{tabular}

\section{Findings}

This section first presents the knowledge constituents for materials use in four domains, i.e., subject matter, pedagogical, contextual, and curricular domains (see Table 2). Then, the processes in which teachers used the materials were delineated with the main focus of demonstrating how teachers mobilized the knowledge constituents to reach their 
pedagogical and curricular goals. Figure 1 depicts the processes of materials use along with the corresponding knowledge constituents.

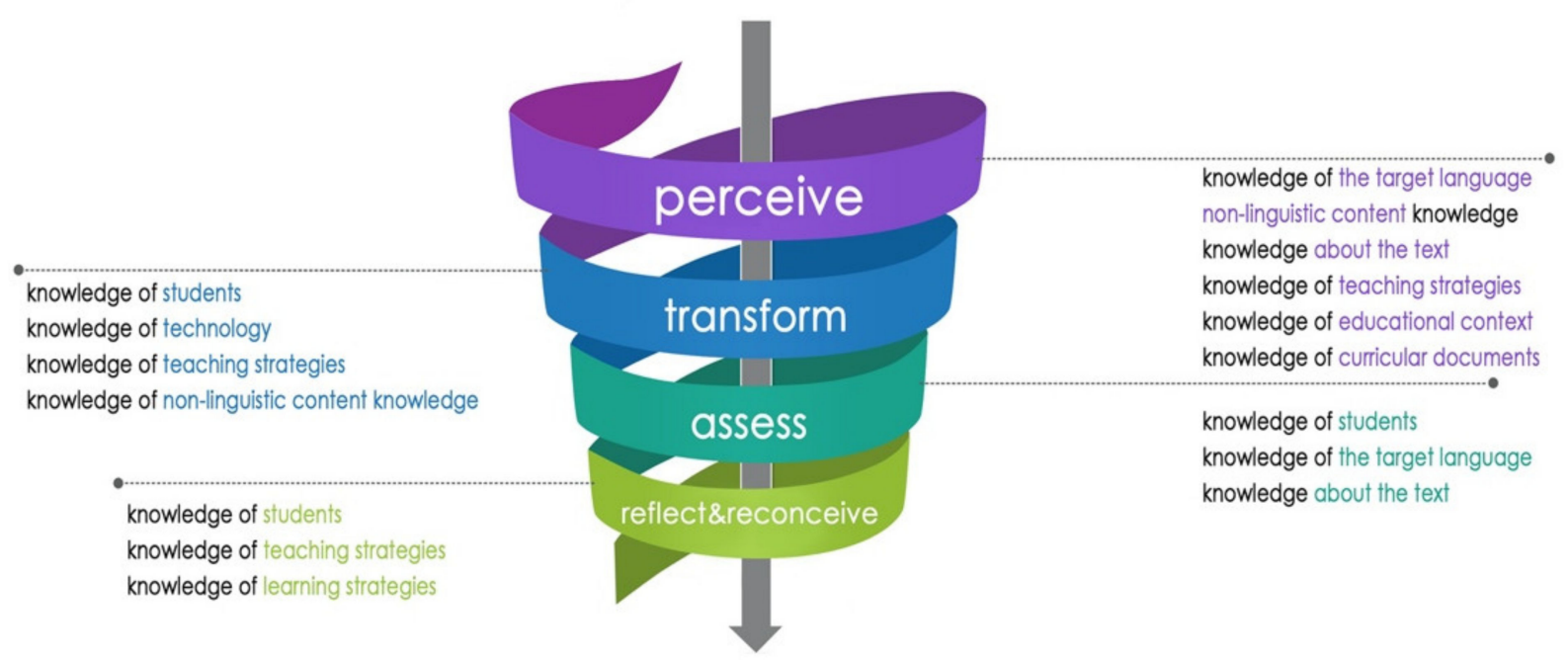

PEDAGOGICAL AND CURRICULAR GOALS

Figure 1. Knowledge constituents via four processes of materials use.

\subsection{The Subject Matter Domain}

Our findings revealed that the subject matter domain consists of knowledge of the target language, non-linguistic content knowledge, and knowledge about the text.

\subsubsection{Knowledge of the Target Language}

Teachers' knowledge of the target language entails the knowledge of the language system, which is crucial to facilitate teachers to activate the linguistic knowledge embodied by the materials. For instance, when teaching the word "glide," T1's and T2's designed and enacted instruction demonstrated different dimensions of knowledge of the target language. Table 3 is T1's slide of "glide."

Table 3. T1's PowerPoint slides.

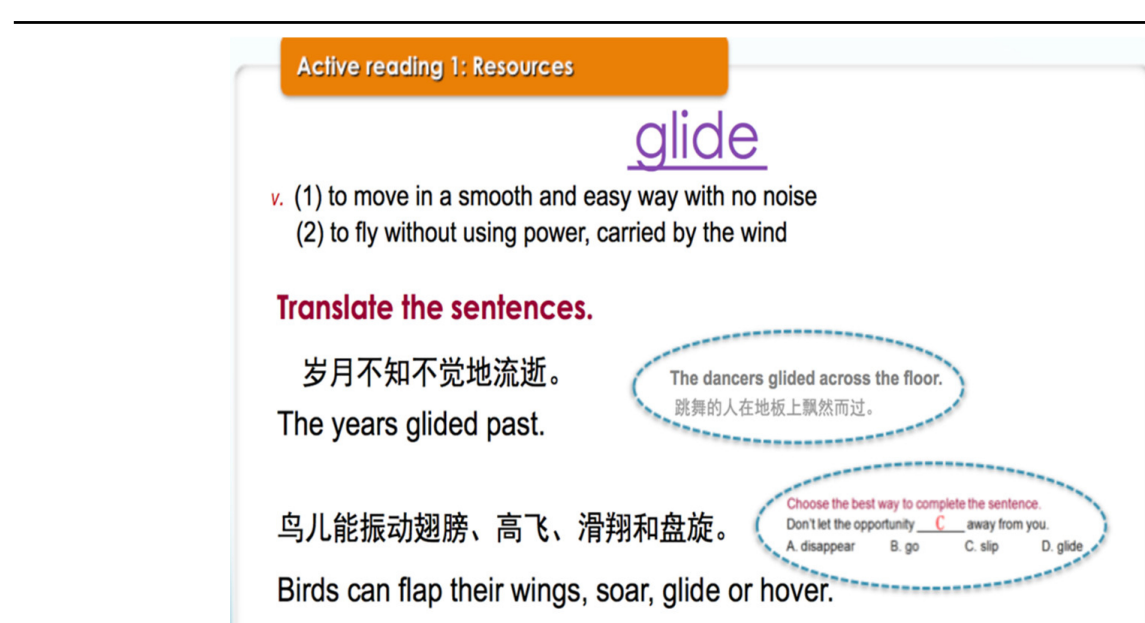


Table 3. Cont.

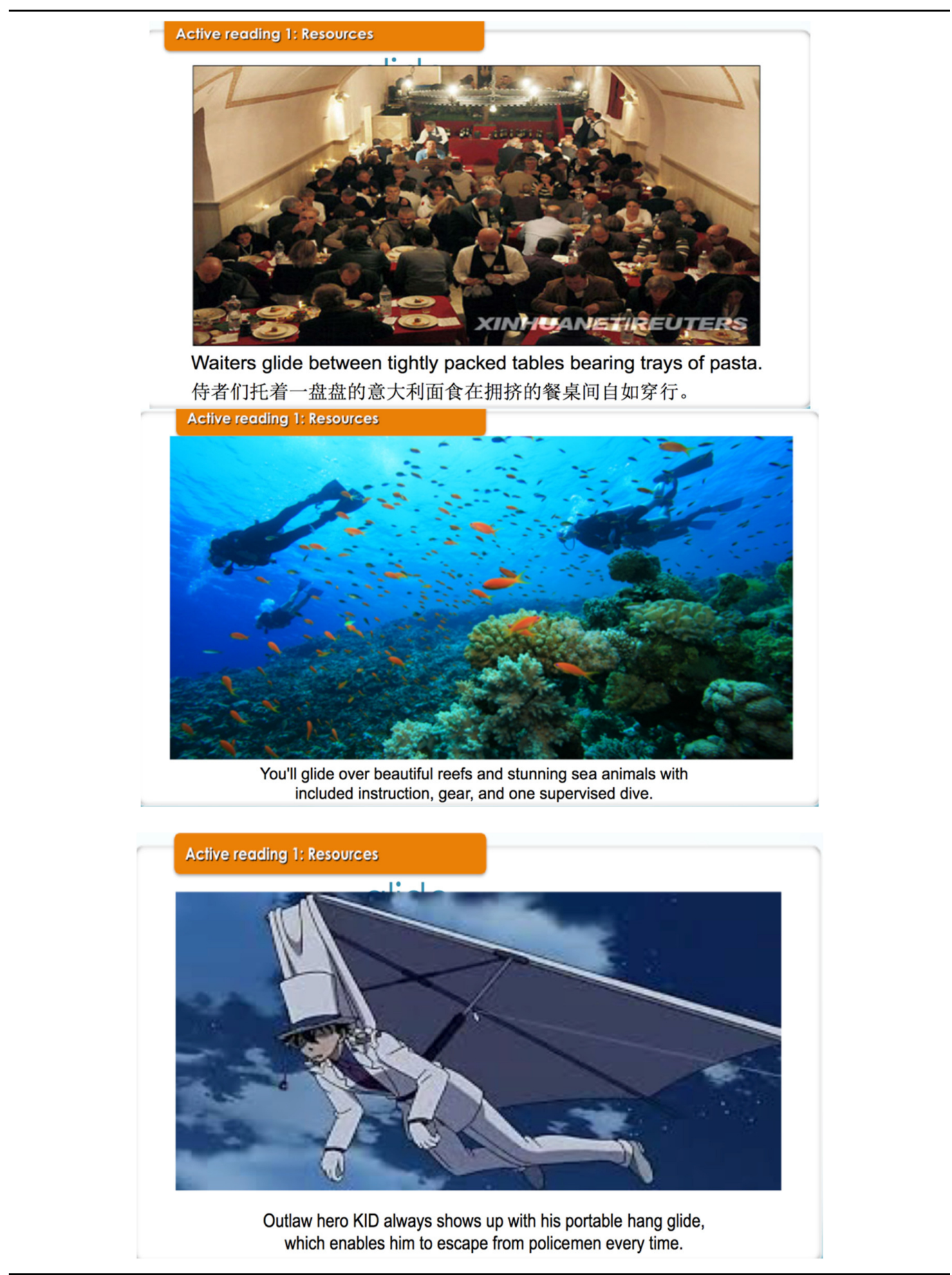

It was shown that $\mathrm{T} 1$ provided four sentence samples with three illustrations in her lesson plan. In her enacted instruction, T1 endeavored to exemplify the usage of the target word 'glide' by analyzing these sample sentences. Her classroom discourse reflected the knowledge of semantics, lexicon, translation, culture, sports, and literature, as shown in Table 4. 
Table 4. Extract 1.

\begin{tabular}{|c|c|c|}
\hline $\begin{array}{l}1 \\
2 \\
3 \\
4 \\
5 \\
6 \\
7 \\
8 \\
9 \\
10 \\
11 \\
12\end{array}$ & $\begin{array}{l}\text { T1: } \\
\text { Ss: } \\
\text { T1: }\end{array}$ & $\begin{array}{l}\text { Ok, look at this picture. What are these people doing? } \\
\text { eating } \\
\text { Why is this place crowded? (.) There are many people inside, so it is crowded. } \\
\text { 侍者们托着一盘盘的意大利面食在拥挤的餐桌间自如穿行。(Waiters glide be- } \\
\text { tween tightly packed tables bearing trays of pasta) Waiters glide between tightly I } \\
\text { packed tables bearing trays of pasta. Bearing 托着 (bearing) We can use glide when R } \\
\text { we describe a movement on the sea as well. Under the sea, 在海里面 (under the I } \\
\text { sea). For instance, you can say you'll glide over beautiful reefs and stunning sea ani- } \\
\text { mals with included instruction, gear, and one supervised dive. 这个地方是什么意思? } \\
\text { (What does it mean here?) glide over, reef 指的是暗礁 (it refers to reef). 澳大利亚 } \\
\text { 有一个很有名的景点叫? (What is the famous resort in Australia?) }\end{array}$ \\
\hline 13 & Ss: & 大堡礁 (Great Barrier Reef) \\
\hline $\begin{array}{l}14 \\
15 \\
16 \\
17 \\
18 \\
19 \\
20 \\
21 \\
22 \\
23 \\
24 \\
25 \\
26\end{array}$ & T1: & $\begin{array}{l}\text { yes, 大堡礁 (Great Barrier Reef). How to say 大堡礁? (Great Barrier Reef) (.) } \\
\text { Great Barrier Reef. Glide 除了在天空中滑翔以外, 还可以在海里面指的是滑 } \\
\text { 动, 在什么之间穿梭 (In addition to gliding in the sky, it can also refer to slid- } \\
\text { ing in the sea and shuttle between things.). All right. 你会在漂亮的礁石和令人 } \\
\text { 震惊的美丽的海底动物间穿梭, 而且你会拥有私人的指导, 很好的指导以及器 } \\
\text { 具 (You will glide over beautiful reefs and stunning sea animals with in- } \\
\text { cluded instruction, gear, and one supervised dive). gear, and one supervised dive, F/D } \\
\text { 和一个专门指导你的教练 (with one supervised dive.) (.) This is KID from De- } \\
\text { tective Code. We can say an outlaw hero, 一个违法的但是英雄的人物 (an out- } \\
\text { law hero). KID always shows up with his portable, portable 可携带的 (porta- } \\
\text { ble) hang glide. Hang glide, 这项运动名字叫滑翔翼 (this sports item is called } \\
\text { hang gliding), which enables him to escape from policemen every time. This is } \\
\text { a hang glide, but this is an advanced hang glide. }\end{array}$ \\
\hline
\end{tabular}

After presenting the second sample sentence in lines 8 and 9, T1 improvised three questions in lines 10,11,12, and 14. The first question was to assess students' mastery of vocabulary (line 10). The second question was to assess students' cultural knowledge, which was raised in L1 (lines 11, 12). The third question was a translation task (line 14). Her students quickly answered the second question in L1 (line 13). However, the last question, i.e., the translation task, received no student responses. T1 then adjusted her interaction mode from IRF to direct telling (line 15). She introduced the other meaning of "glide" in L1 (lines 15,16), which was exemplified in the second sample sentence. A series of non-linguistic content knowledge, i.e., knowledge of culture, literature, and sports was utilized in explaining the third sample sentence (see lines 21 to 26).

By contrast, T2 deleted the information-gap exercise provided in the prescribed PowerPoint slide (see Table 5). In her enacted instruction, T2 transmitted the knowledge from the slide to the class without having any interactions with students, as extract two shows:

Table 5. T2's PowerPoint slide of "glide.".

\begin{tabular}{|l|c|}
\hline \multicolumn{1}{c}{ glide } \\
\hline$v \cdot(1)$ to move in a smooth and easy way with no noise \\
(2) to fly without using power, carried by the wind \\
Translate the sentences. \\
1. The dancers glided across the floor. \\
跳舞的人在地板上飘然而过。 \\
2. 岁月不知不觉地流逝。 \\
The years glided past.
\end{tabular}


Extract 2. T2's enacted vocabulary instruction of "glide.".

T2: glide. 滑翔 (glide) To fly without using power, carried by the wind. The dancers glided across the floor. 跳舞的人在地板上飘然而过 (The dancers glided across the floor.). 岁月不知不觉地流逝 (The years glided past). The years glided past.

Although both teachers had the same pedagogical goal of enlarging students' vocabularies, T1 activated more knowledge resources to orchestrate the instruction and created more chances for her students to engage with the materials and to understand the new vocabulary.

\subsubsection{Non-Linguistic Content Knowledge}

Due to the dual functions of language in language classrooms, i.e., as the medium of instruction and content of teaching, teachers' non-language related content knowledge, such as knowledge of other disciplines, culture, and literature, is a determining factor in the breadth and depth of materials adaptation. For instance, the number of supplementary materials was in relation to the scope of the teacher's content knowledge.

"I may prepare more resources in the area where I know more about them." (T3's postlesson interview).

Conversely, T3 tended to shy away from topics which she was less confident about. But she intended to learn more about those topics, which indicated her agency of learning through the use of the materials, as the excerpt shows:

"But my interest is limited. I don't know how to teach masculine topics. In this case, I will consult others, particularly male teachers." (T3's post-lesson interview).

The "masculine topics", according to T3, refer to topics concerning life related to men, such as brands, names of men, etc. It was revealed that teachers' content knowledge impacted their capacity to construct PCK, i.e., transforming the content into instruction. For instance, T2's rich knowledge of English literature allowed her to enact more instructional episodes on this topic, while her colleagues scarcely found teachable content in the same unit.

"When I was teaching Wuthering Heights in Book 1, I taught the given poems. Actually, I am personally interested in them. I love to teach students something about literature.

But some other teachers said there was nothing to teach, and they didn't know how to teach that unit." (T2's post-lesson interview).

By contrast, T4's inadequacy of content knowledge limited her PCK, as the excerpt reveals:

"The topic of empathy is rather abstract... I am not majoring in this field, so I don't know too much about the topic.... If I am not sure about this, there is no way for me to teach my students explicitly." (T4's post-lesson interview).

In T4's classes, we did not catch any instructional episode regarding the topic of "Empathy" or anywhere from her PowerPoint slides. Therefore, we speculated that she dismissed the material due to her lack of content knowledge.

\subsubsection{Knowledge about the Text}

Teachers' knowledge about the text is composed of the knowledge of the background, the structure, the author's ways of writing, and the relationships among actors and actresses. It frames teachers' strategies for assessing students' comprehension of the passages. For instance, when analyzing a passage about a dog called Hogan and the narrator Soren's mother, T5 and T6 adopted different instructional strategies to attend to students' difficulty in answering the same open-ended question (i.e., what is the possible relationship between the writer and Soren?), as Tables 6 and 7 show: 
Table 6. Extract 3. T5's classroom discourse.

\begin{tabular}{ccc}
\hline 1 & T5: & And what is the possible relationship between the writer and Soren? \\
\hline 2 & Ss: & Friends \\
\hline 3 & T5: & Are they just acquaintances? \\
\hline 5 & Ss: & No, they are friends. \\
6 & T5: & neighbors. All right. By reading paragraphs one and two, do we know \\
whether the writer is a woman or a man?
\end{tabular}

Table 7. Extract 4. T6's classroom discourse.

\begin{tabular}{|c|c|c|}
\hline $\begin{array}{l}1 \\
2\end{array}$ & T6: & $\begin{array}{l}\text { Ok, this text is not so difficult for us to understand. And now, can you } \\
\text { identify the relationship between Soren and the writer? }\end{array}$ \\
\hline 3 & Ss: & $(($ silence $))$ \\
\hline $\begin{array}{l}4 \\
5 \\
6\end{array}$ & T6: & $\begin{array}{l}\text { Let's focus on the sentence. That is in paragraph } 8 \text {. I thought Soren had } \\
\text { given me this child to watch over. He is my first grandchild. So you can } \\
\text { guess, Soren is the writer's son. }\end{array}$ \\
\hline
\end{tabular}

T5's constant prompting, questioning, and elaborating constituted verbal scaffolding. Her students' unsatisfactory responses (lines 2,4 ) triggered her further adaptation of the original question (lines 5, 6, 7). Based on her assessment of students' current level of understanding (lines 2, 4), T5 improvised a much easier yes-no question (lines 6, 7). Upon seeing her students' success in finding the correct answer to this question (line 12), T5 encouraged her students to use the same reading strategy to answer the original question (lines 15,16) along with a series of improvised prompts (lines 17, 18). The adaptation of the original question could not be fulfilled without $\mathrm{T} 5$ 's knowledge of the background, text structure, and underlying relationships among characters in the text.

By contrast, T6 chose to give her students a clue directly (see lines $4,5,6$ ), as Table 7 shows:

It was evident that both teachers were trying to lead students to find out the clue word "grandchild," which implied the relationship between the two characters in the passage. In this regard, both teachers had the same pedagogical goal. However, the knowledge mobilized by both teachers varied. In T5's class, she leveraged the knowledge of the characteristics of the actors and actresses and the knowledge of reading skills to engage students with the text in a meaningful way. T6 rarely used the knowledge of the text, and her teaching was merely indoctrination without any signs of learning. 


\subsection{The Pedagogical Domain}

In the pedagogical domain, the knowledge of teaching strategies and knowledge of learning strategies differentiated the accessibility and comprehensibility of the instruction, and thereby the quality of student learning.

\subsubsection{Knowledge of Teaching Strategies}

It was revealed that teaching strategies are framed by the knowledge possessed by the teacher on the one hand and shaped by the format and content of the materials on the other hand. For instance, it was seen that in most cases, teachers enacted information-gap exercises via IRF or IRE exchanges. Table 8 lists the lead-in task in Unit 7 of Book 2, and Table 9 shows how $\mathrm{T} 1$ and $\mathrm{T} 3$ enacted this same exercise.

Table 8. A lead-in exercise in Unit 7 of Book 2.

\section{Now Complete the Phrases with the Name of an Animal \\ Bat, Fox, Lamb, Lion, Peacock}
(a) as proud as a _ ;
(b) as blind as a
(c) as gentle as a
(d) as cunning as a
(e) as brave as a

Table 9. Part of teachers' enactment of the lead-in exercise.

\begin{tabular}{|c|c|c|c|c|}
\hline Classes & & & Classroom Discourse & \\
\hline \multirow{4}{*}{ T1's class } & 1 & $\mathrm{~T} 1:$ & Let us do this together. As proud as a what? & I \\
\hline & 2 & Ss: & peacock & $\mathbf{R}$ \\
\hline & 3 & T1: & yes, as proud as a peacock. As blind as a? & E/I \\
\hline & 4 & Ss: & bat & $\mathbf{R}$ \\
\hline \multirow{6}{*}{ T3's class } & 5 & & Let's finish the second part of the exercise. It's not & \\
\hline & 6 & T3: & very hard for us. Right? Bat, fox, lamb, lion, & I/E/I \\
\hline & 7 & & peacock. As proud as a? & \\
\hline & 8 & Ss: & $(($ silent $))$ & $\mathbf{R}$ \\
\hline & 9 & T3: & peacock. As blind as a? & $\mathrm{E} / \mathrm{I}$ \\
\hline & 10 & Ss: & bat & $\mathbf{R}$ \\
\hline
\end{tabular}

It was shown that the pedagogy represented in the materials not only confined teaching strategies but could stimulate teachers' design of instruction. For instance, T7 supplemented an oral task inspired by a given translation exercise (see Table 10).

The original task was designed to test students' English-to-Chinese translation skills, as shown in the instruction (i.e., look at the pictures and identify what fables they refer to in Chinese). T7 added five more pictures of Chinese fables and changed the instruction into "Tell the complete stories of these fables in groups." T7 confirmed her intention of activating the potential pedagogical knowledge from the material:

"I'll think about the salient points and what can be extracted from the unit when reading all the materials." (T7's pre-lesson interview).

However, the communication between teachers and the designers of the material was often blocked. For instance, when enacting a lead-in activity (i.e., through reading the blurb of a novel, students are asked to predict what happened to the author without reading the whole passage), T8 encountered divergent students' responses due to his enacted instruction. In his first class, T8 read the printed instruction aloud (i.e., read the blurb of the novel and answer the following questions) and asked his students to talk about the experiences of the author. To his great surprise, most of the students copied the passage without inferring from the context. He then explicitly elaborated on the pedagogical goal 
of the task and asked his students to predict what would happen to the author based on their own experiences and common sense. This time, his students successfully finished the task.

"So in the second class, I had to point out emphatically that not to read the passage and put it away. In this way, the effect was much better." (T8's post-lesson interview).

In addition, teachers not only recruited their knowledge but sought pedagogical knowledge from auxiliary materials. For instance, T4 anticipated an allocation of time on each passage and procedural knowledge for conducting lead-in activities in the Teacher's Guide due to the lack of knowledge in these aspects.

"I will go over the Teacher's Guide each time before preparing for the lesson. It tells me the level of difficulty of the passages. If it is said that active reading one is easy, then I will only spend two periods on it. Besides, it informs me of some skills, e.g., reading skills. I think reading skills are the most important. I will take up these tips. Then it tells you how to conduct a starting point and provides some tips, and gives me some insights." (T4's post-lesson interview).

Table 10. Comparison of the original task and T7's supplementary one.

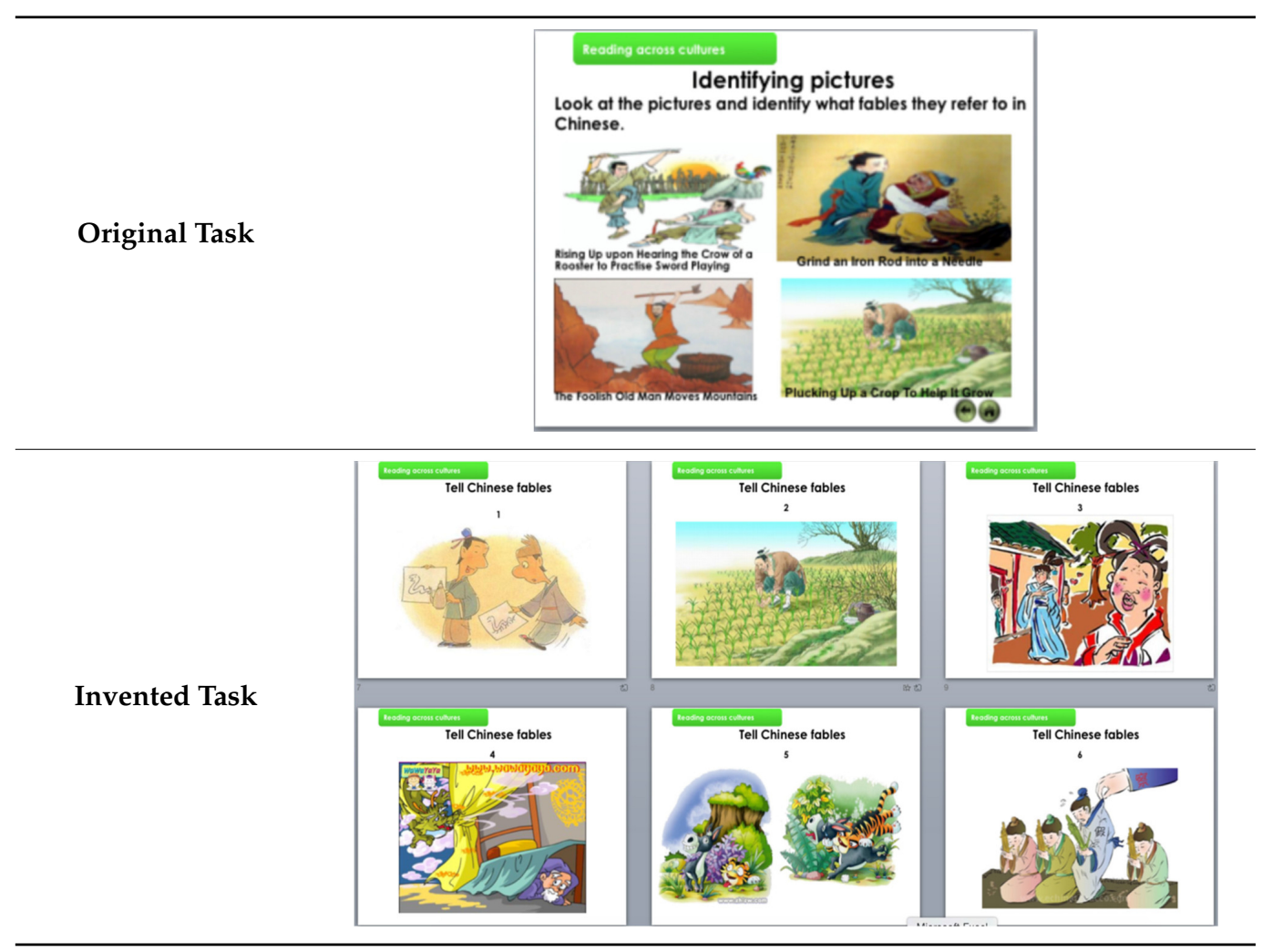

\subsubsection{Knowledge of Learning Strategies}

Teachers' knowledge of learning strategies will allow them to interpret the learning strategies implicitly represented in the materials. As shown in Extract 3, T5 inserted the learning strategy while facilitating students' reading comprehension (i.e., read between the lines in line 19). The analysis of the teaching materials tells us that the general instruction (i.e., read the passage and answer the reading comprehension questions) did not entail any reading strategies needed in the exercise. It depended on teachers to identify and require appropriate learning strategies that students might apply in the exercise.

\subsubsection{Knowledge of Technology}

Teacher's knowledge of technology manifested in the content and modality of teacherprepared materials. It was seen that teachers' supplementary materials were in various 
modalities, including visual (pictures and videos) and audio (recordings) materials, with a wide range of sources, such as movie clips, newspapers, literature, and so on, which in turn reflected teachers' knowledge of technology and their searching skills. For instance, T3 utilized updated presentation software, such as Prezi, to redesign the prescribed PowerPoint slides. She also confirmed this in her post-lesson interview:

"I didn't like the auxiliary PowerPoint slides because I don't think they are so attractive or beautiful. So I'd like to make my own PowerPoint slides." (T3's post-lesson interview).

\subsection{The Contextual Domain}

In the contextual domain, the knowledge of students, including their language proficiency, needs, interests, and preferences, and knowledge of context influenced the selection of supplementary materials.

\subsubsection{Knowledge of Students}

When teaching the unit about animals, T1 invented an activity of letting students describe their favorite animals. In comparison with the original task of eliciting students' descriptions of the given animals, her activity was more affectively engaging. Her consideration of students' preferences informed the design of this activity.

In teaching the topic of university life, T4 added a map with labels of facilities on campus. Compared with the given pictures of two strange campuses, her supplementary diagram was more informative and meaningful to her students, which demonstrated her awareness of students' needs (see Table 11).

Teachers' awareness of students' language competencies was manifested in the selection of materials. For instance, T3's failure of eliciting students' responses to her supplementary video of English idioms about dogs, which required students' high-level listening comprehension skills and intercultural knowledge, was probably due to her unawareness of students' language proficiency. She confirmed this and attributed the failure of this activity to her students' low language proficiency level.

"The students all major in arts. Their English language proficiency level is much lower than their cohorts." (T3's post-lesson interview).

\subsubsection{Knowledge of Educational Contexts}

Teachers' knowledge of educational contexts was manifested when teachers deliberately adapted materials under temporal circumstances. For instance, when final exams or the CET 4 were approaching, T6 would shift her teaching focus from the textbook to the exam-oriented training, as the excerpt shows:

"If College English Test band four is approaching, I may include some training in my class." (T6's interview).

\subsection{The Curricular Domain}

In the curricular domain, the teachers' knowledge of materials use was underpinned by two primary skills: (1) identifying potential teaching content and interpreting the design intentions; and (2) analyzing the institutional and national curriculum. As mentioned earlier, the prescribed textbook equates to the designated curriculum in the target university. It was noted that all teacher participants covered each unit within the stipulated time but creatively adjusted the pace of teaching for each unit and the sequences of teaching contents. In other words, they followed the umbrella rules at the meso (i.e., institutional) level but flexibly utilized their curricular knowledge to create their personalized schedules. Table 12 lists the personalized schedules of each teacher participant. 
Table 11. The university campuses in the prescribed PowerPoint slides and T4's prepared one.

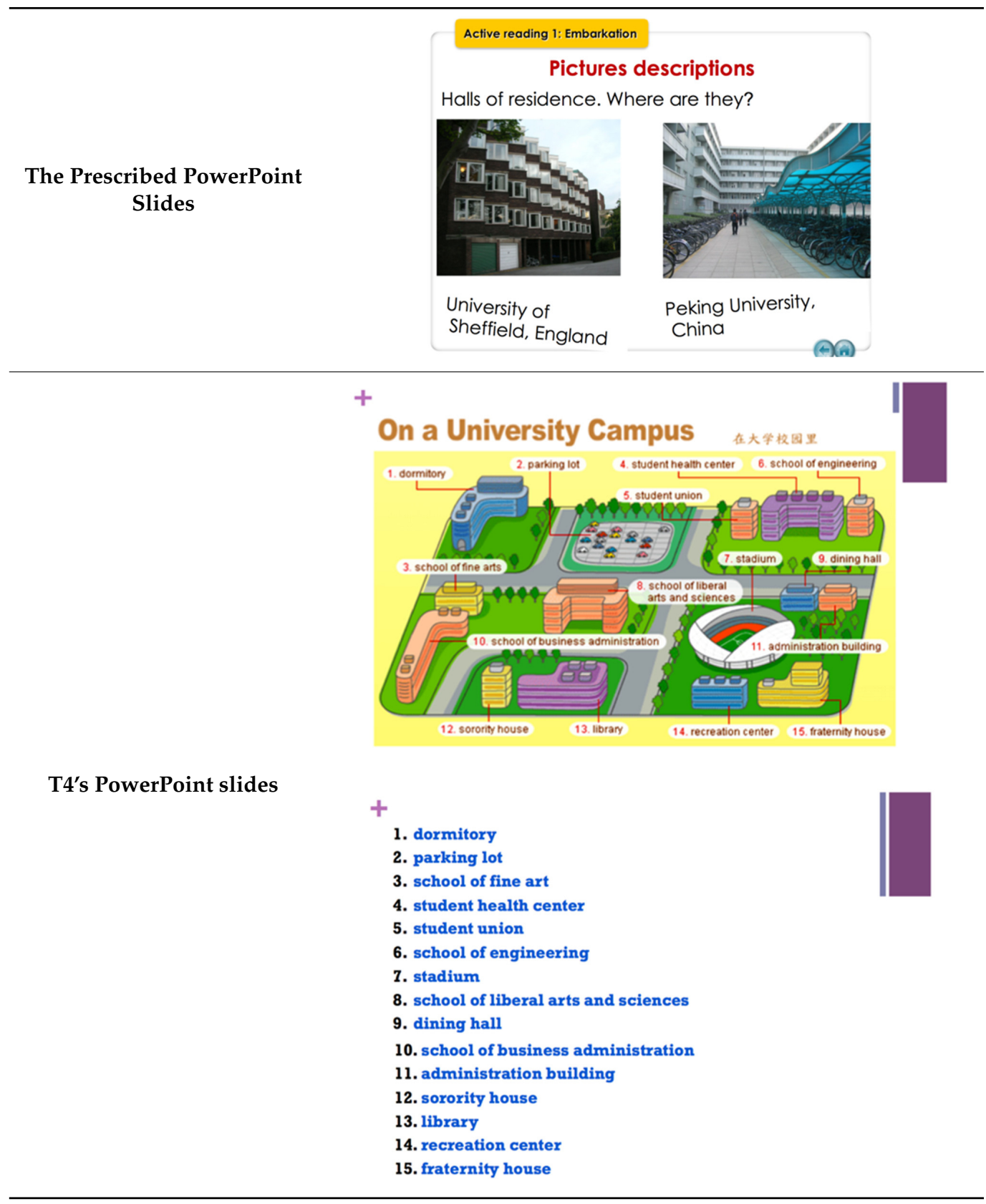

Table 12. Teachers' personalized teaching schedules.

\begin{tabular}{cc}
\hline Teachers & Teaching Schedule \\
\hline T1, T6, T7 & $\begin{array}{c}\text { Three periods for passage one; one period for passage two or } \\
\text { reading across cultures; one period for writing (if it is } \\
\text { academically related); three periods for listening and } \\
\text { speaking courses }\end{array}$ \\
\hline T3, T4, T5 & $\begin{array}{c}\text { Four periods for passage one; two periods for passage two; } \\
\text { two periods for listening and speaking courses }\end{array}$ \\
\hline T2, T8 & $\begin{array}{r}\text { Two periods for passage one; two periods for passage two; } \\
\text { four periods for listening and speaking courses }\end{array}$ \\
\hline
\end{tabular}




\subsubsection{Knowledge of Design Intentions}

The curricular knowledge was also reflected in teachers' success or failure in uncovering the design intentions embodied by the materials. This study disclosed the opacity of the pedagogical knowledge represented in both the Student's Book and Teacher's Guide. For instance, T7 reflected on her students' poor performances when performing the chronological exercise and ascribed this learning outcome to the neglect of raising students' awareness of tense, as the excerpt shows:

"For example, the usage of tense in unit 7. I didn't expect that my students met great trouble in reordering the happenings. Afterward, I considered thoroughly that it must be caused by the usage of tense. They were not aware of the usage of tense, so they ordered them completely wrong. The knowledge like this, if teachers could extract it from the passage, explain it to students, and apply this into other similar scenarios, for instance, let them read a passage with similar language features, then the teaching must be more effective." (T7's post-lesson interview).

After analyzing the given instruction of the task (i.e., number the events in the order in which they happen), we found that the linguistic and pedagogical knowledge required for carrying out this task was completely absent in both the Student's Book and Teacher's Guide. However, due to the lack of transparency of the linguistic and pedagogical knowledge presented in the materials, teachers' enactments of materials were not in line with the intentions of the designers. Thus, curriculum thinking should be added to the framework of PCK, as teachers need to interpret and identify the content and the educational potential contained in the university and national curricula.

It is also worth noting that all the teachers except T3 and T4 acknowledged that they referred to the Teacher's Guide for lesson planning. Most importantly, pertaining to their own knowledge base and teaching goals, teachers sought a wide range of knowledge from the Teacher's Guide. Table 13 summarizes six teachers' purposes of reading the Teacher's Guide and the anticipated knowledge.

Table 13. Six teachers' purposes of reading the Teacher's Guide.

\begin{tabular}{ccc}
\hline Purposes of Reading & Knowledge Sought & Teachers \\
\hline For the inspiration of starting a new topic & $\begin{array}{c}\text { Non-linguistic content knowledge, knowledge of } \\
\text { teaching and learning strategies }\end{array}$ & T1, T5, T6 \\
\hline $\begin{array}{c}\text { For the explication of grammatical } \\
\text { exercises and cultural terminologies }\end{array}$ & $\begin{array}{c}\text { Knowledge of the target language, } \\
\text { non-linguistic knowledge }\end{array}$ & $\mathrm{T} 2, \mathrm{~T} 5, \mathrm{~T} 7$ \\
\hline $\begin{array}{c}\text { For the expansion of the given topics and } \\
\text { the opportunities of teacher development }\end{array}$ & $\begin{array}{c}\text { Knowledge of the target language, non-linguistic } \\
\text { content knowledge, knowledge of teaching strategies }\end{array}$ & T1 \\
\hline $\begin{array}{c}\text { For the specification of conducting } \\
\text { activities and tasks }\end{array}$ & Knowledge of teaching strategies and learning strategies & $\mathrm{T} 1, \mathrm{~T} 2, \mathrm{~T} 5, \mathrm{~T} 6, \mathrm{~T} 8$ \\
\hline
\end{tabular}

It was shown that most of the teachers (i.e., T1, T2, T5, T6, T8) sought the pedagogical knowledge of how to lead in a new topic, how to expand the topics, and how to conduct activities or tasks printed in the Student's Book from the Teacher's Guide. In other words, the Teacher's Guide was designed to facilitate teachers' teaching, particularly when they were in need of certain pedagogical knowledge. However, from their interview data, we noticed that very few teachers commented positively towards the auxiliary function of the Teacher's Guide in this regard.

"When using my former textbooks, I knew well how to expand a topic. But it is hard for me to do so in this series of textbooks based on the facilitating materials in the Teacher's Guide." (T2's post-lesson interview).

"My impression on the passage is I am not clear about what the passage conveys. The Teacher's Guide didn't help me to make it explicit." (T5's post-lesson interview). 
"About the starting point, sometimes, I think it (the Teacher's Guide) doesn't offer enough information for you to lead in a new topic." (T7's post-lesson interview).

Thus, the intended pedagogical knowledge or the designer's intentions were not transparent or explicit either in the Teacher's Guide, which also impeded teachers from using the materials productively and sustainably.

\subsection{Mobilizing Knowledge Constituents via Four Processes of Materials Use}

Here, we demonstrate the four processes of materials use (i.e., perceiving, transforming, reflecting and reconceiving, see Figure 1, cf. 48) wherein teachers drew on an amalgam of knowledge resources to achieve the pedagogical and curricular goals. The teachers first perceived the pedagogy embedded in the materials, wherein they drew on knowledge of the target language, non-linguistic content knowledge, knowledge about the text, and knowledge of teaching strategies to attend to the materials. For instance, the teachers acknowledged that they needed to be conversant with the given topics in order to obtain the meanings of the texts and analyze the passages, as the excerpts show:

"First, I'll read the passage by myself to understand what topic. And I'll just think about some topic-related activities or exercises to introduce this topic to the students." (T1's pre-lesson interview).

"I'll go through the whole passage... At the same time, I can identify the difficult parts of the passage." (T2' pre-lesson interview).

"(read the passage to) get a general sense of the structure of the passage." (T3's pre-lesson interview).

The "difficult parts" that T1 mentioned were the lexico-grammatical features of the text. It was revealed that the teachers lacked knowledge of the target language in terms of its style and lexicon, as T4 said in the post-lesson interview:

"However, some expressions are challenging for me, a non-native speaker. I feel I couldn't catch them. I am not sure whether some expressions are formal or informal, either." (T4' post-lesson interview).

As mentioned in Section 5.1.2, T2's rich knowledge of English literature allowed her to infuse more teachable content than her colleagues. Meanwhile, the pedagogy represented in the materials could stimulate a teacher's pedagogical knowledge and thereby their design of instruction (see the evidence of T7 in Table 8). Aside from recognizing the pedagogical knowledge embedded in the materials, the teachers also recruited their knowledge of educational contexts and curricula documents to design their instruction. We noted that all of the participants adjusted the pace of their teaching for each unit and the sequence of its teaching content. They followed the overall rules for the syllabus stipulated by the institution but flexibly used their curricular knowledge to create their own personalized schedules (see Table 9).

In the second process, the teacher participants transformed the written and digital materials into lived instruction. They drew on their knowledge of students, knowledge of technology, knowledge of teaching strategies, and non-linguistic content knowledge to fulfil their pedagogical goals (see the evidence of T3 in Section 5.3.1).

The third process of materials use is assessing. Knowledge of students, knowledge of the target language, and knowledge about the text were all reflected in the assessments of student learning (see the evidences of T5 and T6 in Section 5.1.3).

In the fourth process, the teachers reflected on unanticipated learning outcomes either by consulting with colleagues to determine their best practices or referring to online resources to reconceive the potential pedagogical knowledge in the materials during or after class (see the evidence of T7 in Section 5.4.1). We found that in order to conduct this given task, knowledge of teaching strategies, knowledge of learning strategies, and knowledge of students were all prerequisites for the teachers. However, the subject matter and pedagogical knowledge required to carry out this task were completely absent from 
the teaching materials. As previously mentioned, to compensate for the pedagogical inadequacy of the textbook, the teachers consulted experts or searched the Internet for relevant information to use the materials more effectively. T7 learned from T8 how to adapt a vocabulary exercise into an oral storytelling practice. T8 supplemented his materials use with a series of vocabulary games. Thus, teachers' reconceiving was not only stimulated by self-reflection, but also stemmed from more knowledge resources. Differences in the teachers' usage of the same materials confirmed the developmental and constructive nature of knowledge regarding materials use.

\section{Discussion}

In sum, this study outlined the knowledge constituents that teachers perceived and mobilized to design and enact instruction via the processes of materials use (see Table 2 and Figure 1).

\subsection{RQ1: Four Domains of Teacher Knowledge for Materials Use}

Teacher knowledge for materials use is by no means generic jargon, as implied in the body of literature on language teacher knowledge [32,44,74]. Rather, it is multidimensional [33], covering subject matter, pedagogical, contextual, and curricular domains.

In the domain of subject matter, our findings indicated that without sufficient knowledge of English language, there was no way for the teachers to impart the necessary linguistic knowledge to their students. Moreover, the scope of non-linguistic content knowledge determined the quality of teaching. In T5's case, her rich knowledge of literature allowed her to infuse more pedagogical meaning into the texts. Conversely, in her teaching, T1 tended to shy away from topics she was less confident about. That the teachers preferred to infuse more familiar knowledge with their teaching aligns with the notion of professional confidence [75], which is determined by how language teachers use their knowledge to teach and how they enact agency.

In the pedagogical domain, it is witnessed that an abundant knowledge of learning strategies will provide teachers with more space to adapt some general and vague instruction printed in the materials and thereby create more learning opportunities for their students. Moreover, the materials under study have the potential to stimulate teachers' pedagogical knowledge. However, the inadequacy of the pedagogical knowledge in the prescribed materials will hinder teachers' interactions with the texts. Therefore, materials should be compiled with both teaching and learning as the priority. The pedagogical meaning or intended curriculum should be transparent and sufficient to cater to teachers' various needs [6], as both teachers and students are consumers of the materials [2].

In the contextual domain, it may be assumed that in the context of the nationalized curriculum, teachers have limited autonomy to authenticate mandatory materials. However, in this study, we witnessed the inevitable need to adapt the materials in language classrooms. On the one hand, materials should be designed by leaving more space for teachers to make necessary modifications and even creation. On the other hand, teachers should take the opportunity to enlarge their content knowledge, identify the academic and non-academic needs and interests of their students, and become well informed about local and global cultures through the use of materials.

In the curricular domain, teachers are supposed to toe the line with the pedagogical intentions of designers and the curricular objectives at the institutional or even national level. This echoes Deng's [76] argument that curriculum thinking should be added to the framework of PCK, as teachers need to interpret and identify the content and the educational potential contained in the institutional and national curricular documents.

\subsection{RQ2: Enacting New Forms of Agency to Enhance Effective Use of Materials}

The study's goal was to conceptualize teacher knowledge in materials use and identify its properties. However, establishing a knowledge base that can guide teachers' practice of materials use is only the first step. Even more importantly, our study attempted to foster the 
growth of teacher knowledge for materials use. Since materials use is a collective activity mediated by different actors and stakeholders, including teachers, learners, administrators, and designers [77], we argue that teacher knowledge for materials use is not a static possession residing in individual teachers but a developmental entity mediated by human and non-human elements in the educational contexts. This view multiplies the potentially relevant actors and brings multiple knowledge resources to the fore, which invokes a series of agency in the processes of materials use [78]. Among them, two new forms of agency from both teachers and materials should be acknowledged and are required to foster the growth of teacher knowledge by using materials.

First, teachers endowed knowledge components with the materials in a series of mediated actions among students, materials, colleagues, and contexts. Teacher knowledge in subject matter, pedagogical, curricular, and contextual domains may drive their actions of materials use. In this light, teachers' agency of gaining and mobilizing multiple knowledge resources through materials use should be acknowledged in current discussions of teachers' work.

Second, textbooks exert forces [20]. They are performative and not inert. Depending on their modes [79], textbooks can enact certain pedagogical activities and sequences. In other words, materials are enmeshed with the social, technical, and human resources [20] and embody a series of forms of agency. What is varied is the mode of responses, which depend on the knowledge and skills of the consumers (e.g., teachers and students). Therefore, the agency of materials should also be recognized and leveraged in the productive use of materials.

In this sense, the practice and knowledge of materials use are mutually constitutive, which have the potential to foster teacher learning in terms of using materials in language education by following the perceiving-reflecting-reconceiving process in one teacher's efforts or collective efforts.

\section{Implications and Limitations}

This study unveiled the types of knowledge that language teachers employed to design and enact instruction through the use of materials. Considering the wide range of teacher knowledge in material use, we propose several implications for teacher development, teacher education, and materials development.

For teachers and teacher educators, the knowledge of materials use should be acknowledged as valuable and unique to EFL teachers' expertise. The notion of teachers' "curriculum literacy" defined by Steiner [80] in mathematics education is also applicable to our TESOL community (p. 3). Most importantly, there is great potential of fostering teacher learning through using materials in language education by teachers individually or in collective efforts. The practice of materials use should then be incorporated into teacher education programs through formal instruction and practicum. In addition to the pragmatic function of preparing teachers for the realities of classroom teaching, materials use is arguably the most effective method to achieve personal and professional development [18].

For materials developers, the materials should not only be compiled for learning as the priority but also for teaching, since most of the teachers in this study intended to search for various knowledge from the Teacher's Guide. Thus, the idea of developing educative materials to equip teachers with more innovative pedagogy initiated in mainstream education $[81,82]$ could also be transferred to the TESOL community.

This study represents a modest step forward of materials use research by conceptually analyzing the knowledge constituents in this teaching practice. However, some limitations must be noted, mainly that the study was restricted to one context, and the number of participants was limited. We suggest that more large-scale studies could examine the components of teacher knowledge of materials use within or beyond a single language teaching context. We believe that the field deserves ongoing investigations in future research to shed light on the sustainability of effective materials use and teacher development. 
Author Contributions: Conceptualization, Z.L.; Data curation, Z.L.; Methodology, Z.L.; Supervision, Y.X.; Writing—original draft, Z.L.; Writing—review \& editing, Y.X. Both authors have read and agreed to the published version of the manuscript.

Funding: The research was not supported by any funding.

Institutional Review Board Statement: The study was conducted according to the guidelines of the Declaration of Helsinki, and approved by the School of Foreign Languages, Zhongnan University of Economics and Law.

Informed Consent Statement: Informed consent was obtained from all subjects involved in the study. Written informed consent has been obtained from the participants to publish this paper.

Data Availability Statement: The data presented in this study are available on request from the first author. The data are not publicly available due to ethical considerations.

Acknowledgments: We would like to thank the editors and reviewers for their efficiency, constructive advice and appreciation of our paper.

Conflicts of Interest: The authors declare no conflict of interest.

\section{Appendix A}

Pre-and Post-observation Teacher Interviews

Pre-observation interview

1. What do you plan to teach in today's lesson?

2. What is your teaching objective for this lesson?

3. What were your sources for the topic and where did you find them?

4. What particular features of the materials were especially helpful or unhelpful in developing your lesson?

5. What types of knowledge have you employed to prepare for the lesson?

Post-observation interview

1. How do you think your lesson went?

2. Why did you use the textbook in particular ways? For example, why did you change your teaching plan?

3. What might influence your decision-making on materials use?

4. What types of knowledge did you feel necessary in accomplishing your teaching objectives?

\section{Appendix B}

Table A1. Transcription conventions.

\begin{tabular}{cc}
\hline Symbol & Meaning \\
\hline Ss: & Several Students at once or the Whole Class Learner (Not Identified) \\
\hline S1: S2: etc & Identified students \\
\hline Italics & Discourse that originates from texts of the given materials \\
\hline$?$ & Phrase final rise in intonation \\
\hline$($ number $)$ & Longer pause, with the length of pause indicated in seconds \\
\hline$\ldots$ & Commentary within the transcript by the transcriber \\
\hline$(($ text $))$ & Translation from first language to second language \\
\hline$($ text $)$ & Untimed perceptible silence \\
\hline$()$. &
\end{tabular}

\section{References}

1. Guerrettaz, A.M.; Engman, M.M.; Matsumoto, Y. Empirically defining language learning and teaching materials in use through sociomaterial perspectives. Mod. Lang. J. 2021, 105, 3-20. [CrossRef] 
2. Harwood, N. English Language Teaching Textbooks: Content, Consumption, Production; Palgrave Macmillan: London, UK, 2014.

3. Harwood, N. What can we learn from mainstream education textbook research? RELC J. 2017, 48, 264-277. [CrossRef]

4. Tomlinson, B.; Masuhara, H. The Complete Guide to the Theory and Practice of Materials Development for Language Learning; Wiley Blackwell: Hoboken, NJ, USA, 2018.

5. Ball, D.L.; Cohen, D.K. Reform by the book: What is-Or might be-The role of curriculum materials in teacher learning and instructional reform? Educ. Res. 1996, 25, 6-14.

6. Remillard, J.T.; Kim, O.K. Knowledge of curriculum embedded mathematics: Exploring a critical domain of teaching. Educ. Stud. Math. 2017, 96, 65-88. [CrossRef]

7. Remillard, J.T.; Taton, J. Rewriting myths about curriculum materials and teaching to new standards. In Challenging Standards: Navigating Conflict and Building Capacity in the Era of the Common Core; Supovitz, J.A., Spillane, J., Eds.; Rowman \& Littlefield: Lanham, MA, USA, 2015; pp. 49-58.

8. Van Lier, L. The Ecology and Semiotic of Language Learning: A Sociocultural Perspective; Kluwer Academic: Philip Drive Norwell, MA, USA, 2004.

9. Darling-Hammond, L.; Bransford, J. (Eds.) Preparing Teachers for a Changing World: What Teachers Should Learn and Be Able to Do; Jossey-Bass: San-Francisco, CA, USA, 2007.

10. Gitomer, D.; Zisk, R. Knowing what teachers know. Rev. Res. Educ. 2015, 39, 1-53. [CrossRef]

11. Grossman, P.; McDonald, M. Back to the future: Directions for research in teaching and teacher education. Am. Educ. Res. J. 2008, 45, 184-205. [CrossRef]

12. Guerrettaz, A.M.; Grandon, M.; Lee, S.; Mathieu, C.; Berwick, A.; Murray, A.; Pourhaji, M. Materials use and development: Synergetic processes and research prospects. Filio 2018, 18, 37-44.

13. Graves, K. Recent books on language materials development and analysis. ELT J. 2019, 73, 337-354. [CrossRef]

14. Tomlinson, B. Materials development for language learning and teaching. Lang. Teach. 2012, 45, 143-179. [CrossRef]

15. Rich, K.M. Examining agency as teachers use mathematics curriculum resources: How professional contexts may support or inhibit student-centered instruction. Teach. Teach. Educ. 2021, 98, 103249. [CrossRef]

16. Harwood, N. Coda: An expanding research agenda for the use of instructional materials. Mod. Lang. J. 2021, 105, 175-184. [CrossRef]

17. Li, Z.; Xu, Y. Unpacking the Processes of Materials Use: An Interdisciplinary Perspective of Language Teachers' Use of Materials in China. SAGE Open 2020, 10, 2158244020977875. [CrossRef]

18. Tomlinson, B. Teacher development through materials development. In Proceedings of the Annual Meeting of the Materials Development Association, Shanghai, China, 9 June 2018.

19. Tsui, A.B.M. The dialectics of theory and practice in teacher knowledge development. In Theory and Practice in EFL Teacher Education: Bridging the Gap; Huttner, J., Mehlmauer-Larcher, B., Reichl, S., Schiftner, B., Eds.; Multilingual Matters: Bristol, UK, 2012; pp. 16-37.

20. Fenwick, T.; Edwards, R.; Sawchuk, P. Emerging Approaches to Educational Research: Tracing the Sociomaterial; Routledge: New York, NY, USA, 2011.

21. Canagarajah, S. Materializing 'competence': Perspectives from international STEM scholars. Mod. Lang. J. 2018, 102, 268-291. [CrossRef]

22. Guerrettaz, A.M. Materials-in-action: Pedagogical ergonomics of a French-as-a-foreign-language classroom. Mod. Lang. J. 2021 105, 39-64. [CrossRef]

23. Jakonen, T. Handling knowledge: Using materials to construct and interpret information requests. J. Pragmat. 2015, 89, 100-112. [CrossRef]

24. Guerrettaz, A.M.; Johnston, B. Materials in the classroom ecology. Mod. Lang. J. 2013, 97, 779-796. [CrossRef]

25. Shawer, S.F. Classroom-level curriculum development: EFL teachers as curriculum-developers, curriculum-makers and curriculum-transmitters. Teach. Teach. Educ. 2010, 26, 173-184. [CrossRef]

26. Li, Z.; Harfitt, G.J. An examination of language teachers' enactment of curriculum materials in the context of a centralized curriculum. Pedagog. Cult. Soc. 2017, 25, 403-416. [CrossRef]

27. Humphries, S. Factors influencing Japanese teachers' adoption of communication-oriented textbooks. In International Perspectives on Materials in ELT; Garton, S., Graves, K., Eds.; Palgrave Macmillan: London, UK, 2014; pp. 253-269.

28. Shawer, S.F. Teacher-driven curriculum development at the classroom level: Implications for curriculum, pedagogy, and teacher training. Teach. Teach. Educ. 2017, 63, 296-313. [CrossRef]

29. Bosompem, E.G. Materials adaptation in Ghana: Teachers' attitudes and practices. In International Perspectives on Materials in ELT; Garton, S., Graves, K., Eds.; Palgrave Macmillan: London, UK, 2014; pp. 253-269.

30. Remillard, J.T. Examining key concepts in research on teachers' use of mathematics curricula. Rev. Educ. Res. 2005, 75, 211-216. [CrossRef]

31. Guerrettaz, A.M.; Johnston, B. A response: The concept of the classroom ecology and the roles of teachers in materials use. Mod. Lang. J. 2014, 98, 671-672. [CrossRef]

32. Richards, J. Competence and performance in language teaching. RELC J. 2010, 41, 101-122. [CrossRef]

33. König, J.; Tachtsoglou, S.; Lammerding, S.; Straub, S.; Nold, G.; Rohde, A. The role of opportunities to learn in teacher preparation for EFL teachers' pedagogical content knowledge. Mod. Lang. J. 2017, 101, 109-127. [CrossRef] 
34. Richards, J. Teachers' maxims in language teaching. TESOL Q. 1996, 30, 281-296. [CrossRef]

35. Woods, D. Teacher Cognition in Language Teaching: Beliefs, Decision-Making and Classroom Practice; Cambridge University Press: Cambridge, UK, 1996.

36. Clandinin, D.J. Personal practical knowledge: A study of teachers' classroom images. Curric. Inq. 1985, 15, 361-385. [CrossRef]

37. Gatbonton, E. Investigating experienced ESL teachers' pedagogical knowledge. Mod. Lang. J. 1999, 83, 35-50. [CrossRef]

38. Gatbonton, E. Looking beyond teachers' classroom behaviour: Novice and experienced ESL teachers' pedagogical knowledge. Lang. Teach. Res. 2008, 12, 161-182. [CrossRef]

39. Mullock, B. The Pedagogical Knowledge Base of Four TESOL Teachers. Mod. Lang. J. 2006, 90, 48-66. [CrossRef]

40. Breen, M.P.; Hird, B.; Milton, M.; Oliver, R.; Thwaite, A. Making sense of language teaching: Teachers' principles and classroom practices. Appl. Linguist. 2001, 22, 470-501. [CrossRef]

41. Golombek, P.R. A study of language teacher's personal practical knowledge. TESOL Q. 1998, 32, 447-464. [CrossRef]

42. Tsang, W.K. Teachers' personal practical knowledge and interactive decisions. Lang. Teach. Res. 2009, 8, 163-198. [CrossRef]

43. Andrews, S. Teacher Language Awareness; Cambridge University Press: Cambridge, UK, 2007.

44. Tsui, A.B.M.; Nicholson, S. A hypermedia database and English as a second language teacher knowledge enrichment. J. Inf. Technol. Teach. Educ. 1999, 8, 215-237. [CrossRef]

45. Shulman, L.S. Those who understand: Knowledge growth in teaching. Educ. Res. 1986, 15, 4-14. [CrossRef]

46. Shulman, L.S. Knowledge and teaching: Foundations of the new reform. Harv. Educ. Rev. 1987, 57, 1-22. [CrossRef]

47. Keller, C.M.; Keller, J.D. Cognition and Tool Use: The Blacksmith at Work; Cambridge University Press: Cambridge, UK, 1996.

48. Brown, M. The teacher-tool relationship: Theorizing the design and use of curriculum materials. In Mathematics Teachers at Work: Connecting Curriculum Materials and Classroom Instruction; Remillard, J.T., Herbel-Eisenmann, B.A., Lloyd, G.M., Eds.; Routledge: Oxforshire, UK, 2009; pp. 17-36.

49. Remillard, J.T. Examining teachers' interactions with curriculum resource to uncover pedagogical design capacity. In Research on Mathematics Textbooks and Teachers' Resources; Fan, L., Trouche, L., Qi, C., Rezat, S., Visnovska, J., Eds.; Springer: Berlin/Heidelberg, Germany, 2018; pp. 69-88.

50. Trouche, L.; Gueudet, G.; Pepin, B. The "Resources" Approach to Mathematics Education; Springer: Berlin/Heidelberg, Germany, 2019.

51. Choppin, J.M. Curriculum-context knowledge: Teacher learning from successive enactment of a standards-based mathematics curriculum. Curric. Inq. 2009, 39, 287-320. [CrossRef]

52. Ben-Peretz, M. The Teacher-Curriculum Encounter: Freeing Teachers from The Tyranny of Texts; State University of New York Press: New York, NY, USA, 1990.

53. Toom, A.; Pyhältö, K.; Rust, F.O.C. Teacher's professional agency in contradictory times. Teach. Teach. Theory Pract. 2015, 21, 615-623. [CrossRef]

54. Kayi-Aydar, H. Language teacher agency: Major theoretical considerations, conceptualizations and methodological choices. In Theorizing and Analyzing Language Teacher Agency; Multilingual Matters: Bristol, UK, 2019; pp. 10-22.

55. Graves, K. Mind the gap: A tale of two curriculum fallacies. Lang. Teach. 2021, 1-13. [CrossRef]

56. Bartell, T.; Cho, C.; Drake, C.; Petchauer, E.; Richmond, G. Teacher agency and resilience in the age of neoliberalism. J. Teach. Educ. 2019, 70, 302-305. [CrossRef]

57. Edward, G. Pre-service teachers' growth as practitioners of developmentally appropriate practice: A Vygotskian analysis of constraints and affordances in the English context. Eur. J. Teach. Educ. 2014, 37, 4-17. [CrossRef]

58. Wertsch, J.V. Mind as Action; Oxford University Press: Oxford, UK, 1998.

59. Miettinen, R. Artifact mediation in Dewey and in cultural-historical activity theory. Mind Cult. Act. 2001, 8, 297-308. [CrossRef]

60. Vygotsky, L.S. Mind in Society: The Development of Higher Mental Process; Harvard University Press: Harvard, USA, 1978.

61. Cohen, D.K.; Ball, D.L. Making change: Instruction and its improvement. Phi Delta Kappan 2001, 83, 73-77. [CrossRef]

62. Li, Z.; Harfitt, G. Understanding language teachers' enactment of content through the use of curriculum materials. Asia Pac. J. Teach. Educ. 2018, 46, 461-477. [CrossRef]

63. Merriam, S.B. Qualitative Research and Case Study Applications in Education, 2nd ed.; Jossey-Bass Publishers: San Francisco, CA, USA, 2007.

64. Yin, R. Case Study Research and Applications: Design and Methods, 6th ed.; Sage Publishing: Los Angeles, CA, USA, 2018.

65. National Bureau of Statistics of China. China Statistical Yearbook; China Statistics Press: Beijing, China, 2018.

66. Xu, J.; Fan, Y. The evolution of the college English curriculum in China (1985-2015): Changes, trends and conflicts. Lang. Policy 2017, 16, 267-289. [CrossRef]

67. Liu, D.; Wu, Z. English Language Education in China: Past and Present; People's Education Press: Beijing, China, 2015.

68. Remillard, J.T.; Heck, D.J. Conceptualizing the curriculum enactment process in mathematics education. ZDM 2014, 46, 705-718. [CrossRef]

69. Patton, M.Q. Qualitative Research and Evaluation Methods; Sage: New York, NY, USA, 2005.

70. Sinclair, J.; Coulthard, M. Towards an Analysis of Discourse: The Language of Teachers and Pupils; Oxford University Press: London, $\mathrm{UK}, 1975$.

71. Corbin, J.; Strauss, A. Basics of Qualitative Research: Techniques and Procedures for Developing Grounded Theor; SAGE Publications, Inc.: New York, NY, USA, 2015. 
72. Irvine-Niakaris, C.; Kiely, R. Reading comprehension in test preparation classes: An analysis of teachers' pedagogical content knowledge in TESOL. TESOL Q. 2015, 49, 369-392. [CrossRef]

73. Oxford, R.L. Language Learning Strategies: What Every Teacher Should Know; Heinle ELT: Boston, MA, USA, 1990.

74. Grossman, P. The Making of a Teacher: Teacher Knowledge and Teacher Education; Teachers College Press: New York, NY, USA, 1990.

75. Freeman, D. Arguing for a knowledge-base in language teacher education, then (1998) and now (2018). Lang. Teach. Res. 2018, 24, 5-16. [CrossRef]

76. Deng, Z. Pedagogical content knowledge reconceived: Bringing curriculum thinking into the conversation on teachers' content knowledge. Teach. Teach. Educ. 2018, 72, 155-164. [CrossRef]

77. Li, Z. Language Teachers at Work: Linking Materials with Classroom Teaching; Springer: Berlin/Heidelberg, Germany, 2020.

78. Tronsmo, E. Investigating teachers' work with multiple knowledge resources in local curriculum development. Pedagog. Cult. Soc. 2019, 27, 555-574. [CrossRef]

79. Remillard, J.T. Modes of engagement: Understanding teachers' transactions with mathematics curriculum resources. In From Text to "Lived" Resources: Mathematics Curriculum Materials and Teacher Development; Gueudet, G., Pepin, B., Trouche, L., Eds.; Springer: Berlin/Heidelberg, Germany, 2012; pp. 105-122.

80. Steiner, D. Curriculum Literacy in Schools of Education? The Hole at the Center of American Teacher Preparation; John Hopkins Institute for Education Policy-Learning First: Baltimore, MA, USA, 2018.

81. Reisman, A.; Fogo, B. Contributions of educative document-based curricular materials to quality of historical instruction. Teach Teach. Educ. 2016, 59, 191-202. [CrossRef]

82. Davis, E.A.; Palincsar, A.S.; Smith, P.S.; Arias, A.M.; Kademian, S.M. Educative curriculum materials: Uptake, impact, and implications for research and design. Educ. Res. 2017, 46, 293-304. [CrossRef] 